\title{
Hypercalcaemia associated with chronic viral hepatitis
}

\author{
J.F. Cadranel ${ }^{1}$, J. Cadranel ${ }^{2,3}$, C. Buffet ${ }^{1}$, O. Ink ${ }^{1}$, G. Pelletier ${ }^{1}$, E. Bismuth ${ }^{1}$ \\ and J.P. Etienne'
}

'Service des Maladies du Foie et de l'Appareil Digestif, Hôpital de Bicêtre, 78 rue du Général Leclerc, 94275 Le Kremlin Bicetre Cédex, ${ }^{2}$ CNRS U 583, Hôpital Necker Enfants Malades and ${ }^{3}$ Service du Professeur Akoun, Hopital Tenon, Paris, France.

\begin{abstract}
Summary: A patient with long lasting non-parathyroid hormone mediated hypercalcaemia occurring within the context of hepatitis B virus chronic hepatitis is reported. Hepatocellular carcinoma and bone malignancy were carefully excluded. The biological pattern associated hypercalcaemia with normal phosphataemia, low nephrogenic cAMP level and high level of tubular reabsorption of phosphate. The usual causes of hypercalcaemia were ruled out. Hypercalcaemia may represent a rare biological feature of some advanced liver disease. The underlying mechanisms remain to be elucidated.
\end{abstract}

\section{Introduction}

Hypercalcaemia has been reported in the course of some cases of cirrhosis complicated by hepatocellular carcinoma or cholangiocarcinoma $a^{1,2}$ and in patients with hepatic tumours in the absence of cirrhosis. ${ }^{3}$ However, in the absence of liver tumour, this metabolic complication has been rarely reported in the course of chronic liver disease. ${ }^{4}$ Nevertheless, most patients in the series of Gerhardt et al. ${ }^{4}$ were supplemented with vitamin $D$ and thus the mechanism of hypercalcaemia was difficult to assess. In order to better understand this rare metabolic event, we have extensively evaluated a patient with a 2-year history of hypercalcaemia associated with hepatitis B virus (HBV) chronic hepatitis.

\section{Case history}

A 53 year old Caucasian man was admitted in June 1987 for exploration of chronic hypercalcaemia that had lasted since April 1986. For 7 years, he had had HBV chronic hepatitis whose outcome had been marked by spontaneous reactivation in April 1986. Serological status for HBV in 1986 showed positive $\mathrm{HBs}$ antigen, $\mathrm{HBe}$ antigen, $\mathrm{HBc}$ antibody (Abbot Laboratory, North Chicago Ill). Liver biopsy showed chronic active hepatitis (CAH) with extensive fibrosis; there were no granulomas. Real time abdominal

Correspondence: Professor C. Buffet, M.D.

Accepted: 14 March 1989 ultrasonography disclosed no space occupying lesions; alphafetoprotein was within the normal range.

He was admitted again in June 1987 because of the persistence of hypercalcaemia. Clinical examination showed jaundice and enlargement of the liver. Tests showed an increase in alanine aminotransferases more than 10 times above the normal range upper limit; total serum bilirubin was $40 \mu \mathrm{mol} / 1$, prothrombin time was $43 \%$ of normal. $\mathrm{HBs}$ antigen, $\mathrm{HBe}$ antibodies and HBV-DNA (Institut Pasteur, Paris) were found in the serum. Delta antibodies, cytomegalovirus, human immunodeficiency virus and herpes virus antibodies were absent from the serum. Liver ultrasonography was normal except for signs of portal hypertension; alphafetoprotein and de-gamma-carboxyprothrombin were both negative. A second liver biopsy showed active cirrhosis.

The results of calcium metabolism and calcium absorption tests are given in Table I. Ionized calcium was elevated, serum phosphorus was normal, 24-hour urinary calcium excretion was mildly elevated; this hypercalcaemia was resorptive according to a calcium absorption test ${ }^{5}$ (Table I). The level of serum immunoreactive parathyroid hormone (PTH) was low using a 53-84 C-terminal radioimmunoassay. Tubular reabsorption of phosphate (TRP) was high and nephrogenic cAMP was low (Table I). These results indicated a mild suppression of parathyroid function. Plasma $25(\mathrm{OH})_{2}$ vitamin $\mathrm{D}_{3}$ and $1-25(\mathrm{OH})_{2}$ $D_{3}$ levels were within the normal range, as were serum thyroxine and vitamin A levels. There were none of the usual causes to account for the hypercalcaemia; 
Table I Results of calcium metabolism and calcium absorption

\begin{tabular}{|c|c|c|}
\hline & Controls & Patient \\
\hline $\begin{array}{l}\text { Serum Ca } \\
(\mathrm{mmol} / 1)\end{array}$ & $2.31 \pm 0.095$ & $2.56-3.16(\mathrm{n}=8)^{*}$ \\
\hline $\begin{array}{l}\text { Ionized } \mathrm{Ca} \\
(\mathrm{mmol} / \mathrm{l})\end{array}$ & $<1.32$ & $1.35-1.52(n=6)$ \\
\hline $\begin{array}{l}\text { Urinary Ca } \\
(\mathrm{mmol} / \mathrm{kg} / 24 \mathrm{~h})\end{array}$ & $<0.100$ & $0.070-0.140(n=8)$ \\
\hline $\begin{array}{l}\text { Post-load } \dagger \text { urinary } \\
\mathrm{Ca} / \mathrm{Cr}(\mathrm{mmol} / \mathrm{mmol})\end{array}$ & $<0.57$ & $0.51-0.62(n=2)$ \\
\hline $\begin{array}{l}\text { Serum P } \\
(\mathrm{mmol} / 1)\end{array}$ & $1.05 \pm 0.08$ & $0.83-1.20(n=8)$ \\
\hline TRP & $0.90 \pm 0.05$ & $0.92-0.94(n=4)$ \\
\hline $\begin{array}{l}\text { Secreted cAMP } \\
(\mathrm{pmol} / \mathrm{ml} \mathrm{GFR})\end{array}$ & $17.4 \pm 2.6$ & $0.5-5.6(n=4)$ \\
\hline $\begin{array}{l}\text { iPTH 53-84 } \\
(\mathrm{pg} / \mathrm{ml})\end{array}$ & $<60$ & $29-35(n=5)$ \\
\hline $\begin{array}{l}\text { Plasma } 25(\mathrm{OH})_{2} \mathrm{D} \\
(\mathrm{ng} / \mathrm{ml})\end{array}$ & $10-30$ & 25 \\
\hline $\begin{array}{l}\text { Plasma } 1,25(\mathrm{OH})_{2} \mathrm{D} \\
(\mathrm{pg} / \mathrm{ml})\end{array}$ & $20-60$ & 24 \\
\hline
\end{tabular}

Ca: calcium, Cr: creatinine, P: phosphorus, TRP: tubular reabsorption of phosphate, cAMP: cyclic adenosine monophosphate, GFR: glomerular filtration rate, iPTH: immunoreactive parathyroid hormone.

All data, except urinary $\mathrm{Ca}$, were obtained in fasting conditions. The patient had a diet containing less than $500 \mathrm{mg}$ of calcium intake per day. Laboratory methods are given in reference 5 .

* Numbers in parentheses are the numbers of values determined.

† Post-load condition was described in reference 5.

clinical and ultrasound evaluation of the neck disclosed no evidence of parathyroid gland enlargement, there was no evidence of hepatocellular carcinoma or chronic bone disease; serum protein electrophoresis showed an increase in gammaglobulins with no monoclonal paraprotein in the serum or urinary immunoelectrophoresis, total body 99-technetium radionuclide scan showed no increased uptake; chest $\mathrm{X}$-ray and kidney ultrasonography were normal. Moreover there was no history of excessive aluminium derivates, milk or alkali intake, thiazide diuretic or vitamin A (and D) supplementation. In May 1988, the hypercalcaemia was still present with no evidence of liver tumour.

\section{References}

1. Oldenberg, W.A., Van Heerden, J.A., Sizemore, G.W., Abboud, C.F. \& Sheedy, P.F. Hypercalcemia and primary hepatic tumours. Arch Surg 1982, 117: $1363-1366$.

\section{Discussion}

The occurrence of hypercalcaemia-associated hypophosphataemia with no parathyroid tumour and in the absence of skeletal metastasis has been called pseudo-hyperparathyroidism. ${ }^{6}$ Hypernephroma and bronchogenic carcinoma account for $60 \%$ of tumours exhibiting this pattern. ${ }^{6}$ Paraneoplasic hypercalcaemia is rare in the setting of hepatocellular carcinoma ${ }^{3}$ High levels of serum PTH have been reported in some cases of paraneoplasic hypercalcaemia associated with primary hepatic tumours; ${ }^{1,7}$ this biological pattern suggested extraparathyroid PTH production. Paraneoplasic hypercalcaemia is characterized by normal or high level PTH, low serum phosphorus level, and low TRP., 3

Recently a very different pattern of hypercalcaemia has been reported by Gerhardt $e t$ al. in eleven patients waiting for liver transplantation with chronic liver disease without hepatic tumour. ${ }^{4}$ These patients had a high serum calcium associated with a high phosphorus level, a low or normal (for the hypercalcaemia) level of PTH and low or normal levels of $25(\mathrm{OH})_{2} \quad \mathrm{D}_{3}$ and $1-25(\mathrm{OH})_{2} D_{3}$. However, several patients were supplemented by vitamin $\mathrm{D}$ and aluminium osteopathy could not be formally excluded in some of the patients with aluminium hydroxide intake. ${ }^{8}$ Moreover, many patients in this series had renal failure and the pathogenesis of hypercalcaemia of these patients was difficult to assess. In contrast, the usual causes of hypercalcaemia such as prolonged immobilization, hyperparathyroidism or pseudo-hyperparathyroidism, bone metastasis, vitamin $\mathrm{D}$ intake or aluminium hydroxide consumption were carefully excluded in the present report. The pattern of hypercalcaemia presented in our case was similar to that of the patients in the series of Gerhardt et al. ${ }^{4}$ Moreover, calcium resorption observed here (Table I) led us to suggest that resorptive factors, i.e. OAF (osteoclast activating factor), TNF (tumour necrotizing factor), interleukin 1, prostaglandin or TGF (transforming growth factor) ${ }^{8-10}$ could be responsible for the hypercalcaemia presented by our patient. Finally, hypercalcaemia could be a rare metabolic feature of some patients with chronic liver failure whatever the cause of liver disease; the underlying mechanisms remain to be established. This report suggests that resorption factors (not identified to date) could be implicated in the pathogenesis of this type of hypercalcaemia.

2. Ihde, D.C., Sherlock, P., Winawer, S.J. et al. Clinical manifestations of hepatoma: a review of six years' experience at a cancer hospital. Am J Med 1974, 56: 83-91. 
3. Audran, M., Hingrat, J.Y., Paineau, J. et al. Hypercalcemie paraneoplasique revelatrice d'un cholangiocarcinome. Regression après hépatectomie. Gastroenterol Clin Biol 1982, 6: 983-988.

4. Gerhardt, A., Greenberg, A., Reilly, J.J. \& Van Thiel, D.H. Hypercalcemia. A complication of advanced chronic liver disease. Arch Intern Med 1987, 147: 274-277.

5. Meyrier, A., Valeyre, D., Bouillon, R. et al. Resorptive versus absorptive hypercalciuria in sarcoidosis: correlations with 25 hydroxy vitamin D3 and 1,25 dihydroxy vitamin D3 and parameters of disease activity. $Q J \mathrm{Med}$ 1985, 54: 269-281.

6. Lafferty, F.W. Pseudohyperparathyroidism. Medicine 1966, 45: 247-260.
7. Knill Jones, R.P., Buckle, R.M., Parsons, V., Calne R.Y. \& Williams, R. Hypercalcemia and increased parathyroid hormone activity in a primary hepatoma. Studies before and after hepatic transplantation. $N$ Engl J Med 1970, 282: 704-708.

8. Williams, J.W., Vera, S.R., Peters, T.G. et al. Biliary excretion of aluminium in aluminium osteodystrophy with liver disease. Ann Intern Med 1986, 104: 782-785.

9. Mundy, G.R., Ibbotson, K.J., D'Souza, S.M. et al. The hypercalcemia of cancer: clinical implication and pathogenic mechanisms. $N$ Engl J Med 1984, 310: $1718-1726$.

10. Mundy, G.R. Hypercalcemia of malignancy revisited. $J$ Clin Invest 1988, 82: 1-6. 